\title{
Phacoemulsification Without Hydro-procedure: A Novel Technique to Deal with Posterior Polar Cataracts.
}

\section{Narayan Bardoloi}

Chandraprabha Eye Hospital, Jorhat

\section{Sandip Sarkar ( $\sim$ drsandip19@gmail.com )}

Jawaharlal Institute of Postgraduate Medical Education and Research https://orcid.org/0000-00029882-0407

\section{Himanshu Das}

Chandraprabha Eye Hospital, Jorhat

\section{Pankaj Suresh Burgute}

Chandraprabha Eye Hospital, Jorhat

\section{Research Article}

Keywords: posterior polar cataract, hydro procedure, phacoemulsification

Posted Date: December 15th, 2021

DOI: https://doi.org/10.21203/rs.3.rs-1142851/v1

License: (9) (1) This work is licensed under a Creative Commons Attribution 4.0 International License. Read Full License 


\section{Abstract}

Purpose: To describe a new phacoemulsification technique without hydro-procedures in patients of posterior polar cataract (PPC) and determine the posterior capsular rate (PCR) and postoperative outcomes.

Methods: After capsulorhexis, we insert the phacoemulsification probe inside the eye and shave the cortex and epinucleus within the capsulorhexis area. Then the phaco probe is buried deep into the center, and an anteroposterior crack is fashioned. Then the probe is placed at 7' o clock to chop away a triangular piece of the nucleus. A similar maneuver is done at a 4' o clock position to take out another piece. The phacoemulsification tip and the chopper are now positioned at the cracked site of the lower fragments. Using the 2 instruments, the fragments are now pushed away and easily emulsified.

Results: We conducted a retrospective study with 115 eyes of 77 patients. The mean age of the study population was $51.87 \pm 14.19$ years (range $22-87$ years). Out of 77 patients, 39 (50.64\%) patients had unilateral PPC, and 38 (49.35\%) had bilateral PPC. PCR occurred in 9 eyes (7.82\%). Two patients had fragment drop, and only $1(0.87 \%)$ patient was left aphakic. Best-corrected visual acuity (BCVA) at postoperative day 30 was $20 / 20$ or better in 102 (88.69\%) eyes, $20 / 32-20 / 80$ was in $11(9.56 \%)$ eyes, and BCVA $20 / 80-20 / 200$ was in $2(1.73 \%)$ eyes.

Conclusion: Phacoemulsification without hydro-procedure is a novel technique that can be successfully implemented in PPC cases and expect an excellent visual outcome.

\section{Introduction}

Posterior polar cataract (PPC) is a developmental cataract where an abnormal adhesion of the posterior capsule to the polar opacity or a pre-existing weakness of the posterior capsule exists [1]. The proposed mechanisms of development of posterior polar cataracts are the persistence of hyaloid artery, invasion of the lens by mesoblastic tissue, and genetic mutations [2-7]. Positive family history has also been linked in $40-55 \%$ of the cases. $[8,9]$ Posterior polar cataract develops during embryonic life or early in infancy and becomes symptomatic at 30-50 years. But, the exact mechanism of formation is yet to be found out. The reported incidence of posterior polar cataracts ranges from 3 to 5 in 1000 with bilateral involvement in $65-80 \%$ cases $[2,3,8-10]$.

Posterior polar cataract (PPC) is characteristically different from other types of cataract because of the inherently weak, thin posterior capsule or the pre-existing defect $[1,8]$. This makes phacoemulsification in PPC a very challenging task. Phacoemulsification of PPC will remain a surgical challenge because of the risk of posterior capsular rupture (PCR) and nucleus drop. Previously published studies reported PCR rates to be varied from 0 to $36 \%$ [8-16]. Hydrodissection is primarily avoided in PPC because it may lead to accidental posterior capsule rupture (PCR) [17]. Over the last few decades, many techniques have been described in the literature to deal with this challenge. "Hydrodelineation"[18], "femto delineation [18]," "inside out delineation"[16], "bimanual Phacoemulsification"[12], "lambda technique"[10], "V" groove 
technique[19], layer by layer" phacoemulsification [20], inverse horseshoe technique"[21], "hook and flip technique"[22] for nucleus removal, are few of these techniques. These techniques have one thing in common: all of them involve some or the other kind of hydro procedure, i.e., hydrodissection or hydrodelineation. We have described a new technique of phacoemulsification in posterior polar cataracts that avoids any kind of hydro procedure. The present study was conducted to evaluate the PCR rate and assess the postoperative outcomes of this new technique.

\section{Methods}

A retrospective, descriptive study was conducted at a tertiary eye care centre in North- East India from January 2017 to December 2019. All the data were collected from the electronic medical records of the hospital. The study was approved by the institutional review board (CPEH/IEC/2019-01-27) of our hospital and adhered the tenets of the Declaration of Helsinki. Informed written consent was obtained from all the participants. Patients with visually significant PPC with at least +1 grade nuclear cataracts were included in the study. Patients with very soft PPC, traumatic cataract, complicated cataract, corneal opacity, uveitis, glaucoma, subluxated cataract, pseudoexfoliation and posterior segment disorders were excluded from the study. A detailed preoperative ophthalmological evaluation including uncorrected visual acuity (UCVA), best-corrected visual acuity (BCVA), intraocular pressure measurement with Goldmann applanation tonometer, slit-lamp examination, and dilated fundus examination to rule out any posterior segment pathology. Pupillary retro illumination was used to check for pre-existing capsular defects. In cases of a dense cataract where fundus examination was inadequate due to hazy media, B-scan ultrasonography was performed. IOL Master-500 (Zeiss, Jena, Germany) used partial coherence laser interferometry for biometry. In cases of hazy media due to dense cataract, the axial length was obtained by immersion A-scan.

\section{Surgical technique:}

All surgeries were performed by a single experienced surgeon (NB were performed under topical anaesthesia with Centurion Vision System with balanced tip (Alcon laboratories, USA) (Video file 1). Two $1 \mathrm{~mm}$ side port incisions were made at 2.30 and 9.30 o'clock. The irrigation cannula of the bimanual I/A was introduced through the left-handed side port, and $5 \mathrm{~mm}$ capsulorhexis was created under irrigation using $30 \mathrm{G}$ bent needle (Figure 1a \& 1b). A $2.2 \mathrm{~mm}$ temporal limbal incision was fashioned. The phacoemulsification probe was inserted into the eye on continuous irrigation mode without any hydro procedure. The parameters: IOP was kept at $60 \mathrm{mmHg}$, phaco power $60 \%$ OZIL, vacuum $90 \mathrm{~mm} \mathrm{Hg}$ and aspiration flow rate (AFR) $24 \mathrm{cc} / \mathrm{min}$. In the first step, shaving of the loose cortex and epinucleus was done within the rhexis margins (Figure 1c). Then some amount of sculpting was done to create a small groove in the middle of the nucleus. The nucleus was held at the designed groove at that vacuum, and chop in situ was done to produce a through and through an anteroposterior crack in the nucleus (Figure 1d) [23]. The probe was then placed at the 7 o'clock position of the nucleus. Then the nucleus was held with vacuum and another chop was made to fashion out a pie-shaped nuclear piece (Figure 1e). The piece was maneuvered into the phaco tip by the second instrument and emulsified. A similar manoeuvre 
at the 4 o'clock position produced another piece of the nucleus which was also emulsified (Figure 1f). The remaining two pieces have adhered at the sub incisional area. These two were cracked, but not separated. The phaco probe and the chopper were placed at the crack of the two pieces (Figure 1g). Steadying the right hand holding the phaco probe, the chopper in the left hand separated the piece on the left and carried it towards the 6 o'clock position and emulsified (Figure 1h). The other piece, which was then free of any attachment, could be easily rotated to be emulsified in the iris or capsular plane (Figure 1i). In the cases of harder nuclei, a central crater was made and then the subsequent chops were being performed as discussed above. Most of the time the epinucleus came out along with the nuclear pieces (Figure 1j). It was pulled to the centre from all sides to be aspirated at the end. On a few of occasions, after chopping the first two fragments we did not emulsify them instantly, we separate all four pieces and then started the emulsification. Before removing the phaco probe from the anterior chamber, every time we had filled the AC with dispersive OVD (Viscoat, Alcon laboratories) to prevent the sudden collapse of the AC (Figure 1k). Cortical material was aspirated using Bimanual irrigation \& aspiration cannula. A single-piece hydrophobic acrylic foldable intraocular lens (IOL) was implanted into the capsular bag (Figure 1I). Preservative-free moxifloxacin (Vigamox, Alcon laboratories, USA) $0.5 \mathrm{ml}$ was injected into the anterior chamber. Main incision and side port incisions were sealed using stromal hydration.

\section{Results}

Table 1 demonstrates the baseline characteristics of all the patients. In our study population total, 77 patients were there; among them, 47 (61.03\%) were male, and 30 (38.96\%) were female patients. The mean age of the study population was $51.87 \pm 14.19$ years (range 22-87 years). Out of 77 patients, 39 $(50.64 \%)$ patients had unilateral posterior polar cataracts and 38 (49.35\%) patients had bilateral involvement. 
Table 1

Baseline demographic of the patients

\begin{tabular}{|lll|}
\hline Parameters & \multicolumn{2}{l|}{ Values } \\
\hline No of patients & & 77 \\
\hline Gender & Male & $47(61.03 \%)$ \\
\cline { 2 - 3 } & Female & $30(38.96 \%)$ \\
\hline Age & Mean \pm SD & $51.87 \pm 14.19$ years \\
\cline { 2 - 3 } & Range & $22-87$ years \\
\hline No of eyes $(\mathbf{n})$ & & 115 \\
\hline & Unilateral PPC & $39(50.64 \%)$ \\
\cline { 2 - 3 } & Bilateral PPC & $38(49.35 \%)$ \\
\hline Uncorrected Visual Acquity (UCVA) & Mean \pm SD & $0.867 \pm 0.57$ logMAR \\
\hline Best Corrected Visual Acquity (BCVA) & Mean \pm SD & $0.523 \pm 0.40$ logMAR \\
\hline Intraocular pressure (mmHg) & Mean \pm SD & $13.34 \pm 2.34$ \\
\hline Endothelial cell count (cells/mm²) & Mean \pm SD & $2356 \pm 256$ \\
\hline
\end{tabular}

Phacoemulsification was completed in all 115 cases. Out of 115 operated eyes, PCR occurred in 9 eyes (7.82\%) (Table 2). Except in 2 eyes, the PCR occurred during the removal of the plaque. Automated anterior vitrectomy (AAV) was performed in every PCR case. Except for 1 case where anterior capsular support was inadequate, a 3 Piece hydrophobic intraocular lens (IOL) was implanted over the sulcus in every other patient. The 2 cases which had PCR during chopping ended up with a slight fragment droop into the vitreous cavity. Triamcinolone acetonide-assisted AAV was performed in both cases. One patient was having adequate capsular support, so a 3-piece hydrophobic IOL has implanted and pars plana vitrectomy with the fragmentation of the dropped fragment was done by the vitreoretinal surgeon on the same day. But, the other patient had inadequate capsular support, we did complete anterior vitrectomy and scleral fixated intraocular lens (SFIOL) was implanted 2 weeks later by our vitreoretinal surgeon. 
Table 2

Demographic of all PCR cases

\begin{tabular}{|c|c|c|c|c|c|c|c|}
\hline $\begin{array}{l}\text { SI } \\
\text { No }\end{array}$ & Age & Sex & $\begin{array}{l}\text { Operated } \\
\text { eye }\end{array}$ & $\begin{array}{l}\text { PreOp } \\
\text { BCVA }\end{array}$ & PCR occured & $\begin{array}{l}\text { Post op } \\
\text { BCVA on } \\
\text { Day30 }\end{array}$ & Remarks \\
\hline 1 & 54 & $M$ & OD & $20 / 40$ & Plaque removal & $20 / 32$ & $\begin{array}{l}\text { AAV,3-P IOL in } \\
\text { sulcus }\end{array}$ \\
\hline 2 & 62 & $M$ & OS & $20 / 40$ & $\begin{array}{l}\text { Fragment } \\
\text { removal }\end{array}$ & $20 / 25$ & $\begin{array}{l}\text { AAV,3-P IOL in } \\
\text { sulcus }\end{array}$ \\
\hline 3 & 68 & M & OS & $20 / 125$ & Plaque removal & $20 / 63$ & $\begin{array}{l}\text { AAV,3-P IOL in } \\
\text { sulcus }\end{array}$ \\
\hline 4 & 72 & $\mathrm{~F}$ & OD & $20 / 63$ & Plaque removal & $20 / 40$ & $\begin{array}{l}\text { AAV,3-P IOL in } \\
\text { sulcus }\end{array}$ \\
\hline \multirow[t]{2}{*}{5} & 62 & $M$ & os & CF $3 \mathrm{mt}$ & chopping & $20 / 200$ & Nuclear drop, \\
\hline & & & & & & & $\begin{array}{l}\text { AAV,3-P IOL in } \\
\text { sulcus }\end{array}$ \\
\hline 6 & 71 & $M$ & OD & $20 / 200$ & Plaque removal & $20 / 40$ & $\begin{array}{l}\text { AAV,3-P IOL in } \\
\text { sulcus }\end{array}$ \\
\hline 7 & 31 & $M$ & OS & $20 / 80$ & $\begin{array}{l}\text { Epinucleus } \\
\text { removal }\end{array}$ & $20 / 32$ & $\begin{array}{l}\text { AAV,3-P IOL in } \\
\text { sulcus }\end{array}$ \\
\hline 8 & 33 & $M$ & os & $20 / 40$ & Plaque removal & $20 / 32$ & $\begin{array}{l}\text { AAV,3-P IOL in } \\
\text { sulcus }\end{array}$ \\
\hline 9 & 68 & $\mathrm{~F}$ & OD & CF $2 \mathrm{mt}$ & Chopping & $20 / 200$ & Aphakia, SFIOL \\
\hline
\end{tabular}

The mean best-corrected visual acquity (BCVA) improved from a preoperative value of $0.523 \pm 0.40 \mathrm{log}$ MAR to $0.119 \pm 0.05 \log$ MAR at 1 month postoperatively $(P<0.00001$, Wilcoxon-ranked sum test). Meanwhile, best-corrected visual acuity (BCVA) at postoperative day 30 was 20/20 or better in 102 (88.69\%) eyes, 20/32-20/80 was in 11(9.56\%) eyes, and BCVA 20/80-20/200 was in $2(1.73 \%)$ eyes. One patient with Proliferative Diabetic Retinopathy (PDR) had final postoperative BCVA of $6 / 24$. There was no case of pre-existing posterior capsular defect. Primary IOL implantation was successful in 114 cases. Secondary IOL (scleral fixated IOL) implantation was needed in 1case. There was no case of nucleus drop, but nuclear fragment drop was noted occurred in 2 cases. Only $1(0.87 \%)$ case left aphakic due to inadequate capsular support.

\section{Discussion}


Bardoloi et al. has successfully described the phacoemulsification without hydro procedure technique [24, 25]. Incorporating this technique into phacoemulsification of PPC gives us an advantage as hydrodissection could be harmful in this type of patients. We adhere to four basic principles while applying this procedure in PPC surgery. The first principle is the creation of a $5 \mathrm{~mm}$ sized capsulorhexis. The size of the capsulorhexis assumes much importance when there is PCR and an intraocular lens (IOL) has to be placed in sulcus and optic captured. Secondly, the phaco parameters were kept on the lower side along with low bottle height. This ensures less turbulence in an already compromised eye with vulnerable posterior capsule. Thirdly, the Anterior Chamber is always filled up by injecting ophthalmic viscosurgical devices (OVD) before withdrawing phaco or irrigating handpieces from the eye. This prevents vitreous pressure on the posterior capsule. Adequate use of the chopper by the left hand to pull or scoop out the chopped fragments from the bag constitutes the fourth principle applied in this technique. This prevents stress on the posterior capsule.

Phacoemulsification in posterior polar cataracts has been a challenge for cataract surgeons due to its propensity to produce more PCR than other cataracts. Till date, there is no fool proof technique to tackle the challenges of PPC. Many techniques have been described in the literature to minimize the risk of posterior capsule rupture in this type of cataract. Hydrodelineation, inside-out hydrodelineation, Femto delineation, lambda technique of phacoemulsification, etc., are many such techniques.[10,16, 18] All these techniques involve some sort of hydro procedure. With any kind of hydro procedure, even with hydrodelineation in PPC, the risk of PCR increases due to the accidental subcapsular injection of the fluid and may cause an early tear in the posterior capsule.[16] Vasavada et. al; recommended "inside out hydrodelineation" for phacoemulsification in PPC, but in their series also 8\% PCR rate was observed.[16] To prevent the PCR, Hua et al. did Phacoemulsification with hydrodelineation and OVD-assisted hydrodissection in PPC.[26] They also noted 16\% PCR in their case series.

Our technique is different in that respect, as no hydro procedure was performed, negating the minimum risk involved. To the best of our knowledge, this is the first published study in literature where phacoemulsification has been performed without any hydro procedure in posterior polar cataracts.

PPC is characterized by a central, dense, disk-shaped opacity located on the posterior capsule with concentric rings around the central plaque opacity that appear like a bull's eye. The opacity has a coneshaped projection in the subcapsular region of the central posterior cortex. There are two types of PPC: stationary and the other is progressive. The stationary type of PPC is compatible with good vision, and such patients don't seek early surgery. In progressive PPC, changes occur in the posterior cortex in the form of radiating rider opacities. Patients with progressive opacity become more symptomatic and come for early intervention.[1]

One may ask why we avoided any hydro procedure in our technique? The plaque in PPC may or may not be attached to the posterior capsule. The posterior capsule underneath the plaque may be extremely thin or maybe normal. It is very difficult to put forward a firm opinion regarding the status of the posterior capsule or adherence of the plaque to it. The idea of delineating the posterior polar cataract by hydro, 
Visco, or Femto is to disassemble the endonucleus-epinucleus complex so that the vulnerable area at the posterior capsule remains protected. The high incidence of posterior capsule rupture during surgery might be due to two reasons. First, the plaque might be tight adherence to an otherwise normal capsule. Second, the posterior capsule underlying the plaque is fragile and can get ruptured with minimal trauma. Though looks innocuous, hydro delamination may cause inadvertent hydro dissection, which may be dangerous in some PPC.[16] Forceful passage of fluid between the plaque and the capsule on attempted hydrodeliniation may cause a tear in the capsule.[27] Considering all these, we have developed the technique of phacoemulsification without hydro procedure which causes the least disturbance to the integrity of the posterior capsule in PPC.

Table 3 showing that the incidence of PCR in our study is $7.82 \%$, which, when compared to other studies, is substantially lower in comparison to previously published studies like; Osher et al reported a $26 \%$ PCR rate, Vasavada et al reported 36\% incidence, Hayashi et al reported 7.1\% PCR, Haripriya et al reported $12.5 \%$ PCR, while Malhotra et al reported 7.6\% incidence rate of PCR in their respective studies.[8, 9, 11, $12,28]$ 
Table 3

Comparison of outcomes between our Study and previously published studies

\begin{tabular}{|c|c|c|c|c|}
\hline Authors & Technique & $\begin{array}{l}\text { Total no of } \\
\text { eyes in } \\
\text { series }\end{array}$ & $\begin{array}{l}\text { PCR } \\
\text { rate }\end{array}$ & outcomes \\
\hline $\begin{array}{l}\text { Osher et } \\
\text { al[8] }\end{array}$ & $\begin{array}{l}\text { Low power, low infusion, slow- } \\
\text { motion phaco }(+ \\
\text { hydrodissection })\end{array}$ & 31 & $\begin{array}{l}26 \% \\
(8 \\
\text { eyes) }\end{array}$ & $\begin{array}{l}\text { Vitreous loss } 13 \%(4 / 31) \\
\text { Decentered IOL } 6 \%(2 / 31)\end{array}$ \\
\hline $\begin{array}{l}\text { Vasavada } \\
\text { and } \\
\text { Singh[9] }\end{array}$ & Delineation & 25 & $\begin{array}{l}36 \% \\
(9 \\
\text { eyes })\end{array}$ & \\
\hline \multirow{2}{*}{$\begin{array}{l}\text { Lee and } \\
\text { Lee[10] }\end{array}$} & \multirow[t]{2}{*}{ Delineation } & \multirow[t]{2}{*}{25} & \multirow{2}{*}{$\begin{array}{l}8 \%(2 \\
\text { eyes) }\end{array}$} & RD 7\% (2/28) \\
\hline & & & & $\begin{array}{l}\text { Dropped nucleus } 4 \% \\
(1 / 25)\end{array}$ \\
\hline $\begin{array}{l}\text { Vasavada } \\
\text { and Raj } \\
{[16]}\end{array}$ & Inside out delineation & 25 & $\begin{array}{l}8 \%(2 \\
\text { eyes })\end{array}$ & $\begin{array}{l}\text { Dropped nucleus } 4 \% \\
(1 / 25)\end{array}$ \\
\hline $\begin{array}{l}\text { Haripriya et } \\
\text { al. [12] }\end{array}$ & Bimanual microphaco & 8 & $\begin{array}{l}12.5 \% \\
(1 \\
\text { eye })\end{array}$ & \\
\hline $\begin{array}{l}\text { Das et } \\
\text { al[14] }\end{array}$ & $\begin{array}{l}\text { Chip and flip for soft cataracts. } \\
\text { Stop and chop for hard } \\
\text { cataracts. }\end{array}$ & 81 & $\begin{array}{l}31 \% \\
(25 \\
\text { eyes })\end{array}$ & $\begin{array}{l}\text { Dropped nucleus } 3 \% \\
(2 / 81)\end{array}$ \\
\hline $\begin{array}{l}\text { Malhotra, } \\
\text { et al[28] }\end{array}$ & $\begin{array}{l}\text { V or lambda sculpting, } \\
\text { Viscodissection of epinucleus }\end{array}$ & 80 & $\begin{array}{l}7.5 \% \\
(6 \\
\text { eyes })\end{array}$ & Aphakia - 1.25\% (1/80) \\
\hline $\begin{array}{l}\text { Saitiri H et } \\
\text { al [13] }\end{array}$ & $\begin{array}{l}\text { Hydrodissection-free } \\
\text { phacoemulsification technique' }\end{array}$ & 38 & 0 & \\
\hline $\begin{array}{l}\text { Salahuddin } \\
\text { et al. [21] }\end{array}$ & Inverse horse-shoe technique & 28 & $7.1 \%$ & $\begin{array}{l}\text { Two patients left with } \\
\text { plaque }\end{array}$ \\
\hline Hua et & hydrodelineation & 24 & $16.6 \%$ & \\
\hline & $\begin{array}{l}\text { and OVD-assisted } \\
\text { hydrodissection }\end{array}$ & & & \\
\hline $\begin{array}{l}\text { Current } \\
\text { study }\end{array}$ & $\begin{array}{l}\text { Phacoemulsification without } \\
\text { hydro-procedure }\end{array}$ & 115 & $\begin{array}{l}7.82 \% \\
(9 \\
\text { eyes })\end{array}$ & $\begin{array}{l}1 \text { aphakia, } \\
1 \text { fragment drop }\end{array}$ \\
\hline
\end{tabular}

On the other hand, if there is dehiscence or tear in the posterior capsule, it can be ascertained to a great extent by examination under the slit lamp, AS-OCT or Pentacam. There was not a single eye with a preexisting tear in our series. Compared to the previously published study, the incidence of PCR in our finding is a little surprising. Geographical variation may be one explanation for our study's lack of such a type of posterior polar cataract. 
There were 38 cases of bilateral PPC, who had undergone bilateral cataract surgery sequentially. The mean time difference between the first and the second eye operation is $11.28 \pm 7.28$ months, ranging from 1-71 months. The posterior capsular rupture occurred in 4 eyes among them. In 2 patients, the PCR was in the first eye, while in another two patients, it occurred in the second eye. So, this implies that the fate of the second eye surgery has no bearing on the result of the first eye.

In our case series, $102(88.69 \%)$ patients got BCVA 20/20 or better after one month postoperatively, which is better than a few of the previously published studies like Malhotra et al. reported $55(68.75 \%)$ cases gaining BCVA of $20 / 20$ or better, Salahuddin reported $85.7 \%$ cases achieving BCVA $20 / 40$ or better, Osher et al reported $96.7 \%$ patients gaining BCVA $20 / 40$ or better. $[8,21,28]$

Limitation: Our study is descriptive, non-comparative and retrospective in nature. One major limitation of our technique is that we cannot apply it to soft PPC cataracts. An experimental study involving 2 groups, i,e. one without hydro procedure and the other with a hydro procedure, especially that done with hydrodelamination would have given a direct comparison between the two techniques.

Despite all these techniques and technologies, the incidence of PCR in PPC is still 7\%. This is quite high in comparison to the rate of PCR in general phacoemulsification surgery. This indicates that we are still to understand the behavior of PPC, and most of the time we cannot prevent what is destined to happen.

\section{Declarations}

\section{Declaration of the patient consent:}

Informed consent was obtained from all individual participants included in the study.

\section{Declaration of conflicting interests}

The author(s) declared no potential conflicts of interest with respect to the research, authorship, and/or publication of this article.

\section{Funding}

The author(s) received no financial support for the research, authorship, and/or publication of this article.

\section{References}

1. Duke-Elder S (1964) Normal and abnormal development; congenital deformities. System of ophthalmology 3:648-650

2. Consultation section. Cataract surgical problem.J Cataract Refract Surg23(6):819-824 
3. Vogt G, Horváth-Puhó E, Czeizel E (2006) A population-based case-control study of isolated congenital cataract. Orv Hetil 147(23):1077-1084

4. Greeves R (1914) Two cases of microphthalmia. Trans Ophthalmol Soc UK 34:289-300

5. Szily AV (1938) The Doyne Memorial Lecture: the contribution of pathological examination to elucidation of the problems of cataract. Trans Ophthalmol Soc UK 58(11):595-660

6. Addison P, Berry V, Ionides A, Francis P, Bhattacharya S, Moore A (2005) Posterior polar cataract is the predominant consequence of a recurrent mutation in the PITX3 gene. J Med Genet 42(4):313-313

7. Berry V, Francis P, Reddy MA, Collyer D, Vithana E, MacKay I, Dawson G, Carey AH, Moore A, Bhattacharya SS (2001) Alpha-B crystallin gene (CRYAB) mutation causes dominant congenital posterior polar cataract in humans. The American Journal of Human Genetics 69(5):1141-1145

8. Osher RH, Yu BC-Y, Koch DD (1990) Posterior polar cataracts: a predisposition to intraoperative posterior capsular rupture. Journal of Cataract \& Refractive Surgery 16(2):157-162

9. Vasavada A, Singh R (1999) Phacoemulsification in eyes with posterior polar cataract. J Cataract Refract Surg 25(2):238-245

10. Lee M, Lee Y (2003) Phacoemulsification of posterior polar cataracts-a surgical challenge. $\mathrm{Br} \mathrm{J}$ Ophthalmol 87(11):1426-1427

11. Hayashi K, Hayashi H, Nakao F, Hayashi F (2003) Outcomes of surgery for posterior polar cataract. Journal of Cataract \& Refractive Surgery 29(1):45-49

12. Haripriya A, Aravind S, Vadi K, Natchiar G (2006) Bimanual microphaco for posterior polar cataracts. Journal of Cataract \& Refractive Surgery 32(6):914-917

13. Siatiri H, Moghimi S (2006) Posterior polar cataract: minimizing risk of posterior capsule rupture. Eye 20(7):814-816

14. Das S, Khanna R, Mohiuddin SM, Ramamurthy B (2008) Surgical and visual outcomes for posterior polar cataract. Br J Ophthalmol 92(11):1476-1478

15. Nagappa S, Das S, Kurian M, Braganza A, Shetty R, Shetty B (2011) Modified technique for epinucleus removal in posterior polar cataract. Ophthalmic Surgery, Lasers and Imaging Retina 42(1):78-80

16. Vasavada AR, Raj SM (2004) Inside-out delineation. Journal of Cataract \& Refractive Surgery 30(6):1167-1169

17. Vasavada AR, Vasavada VA (2017) Managing the posterior polar cataract: an update. Indian J Ophthalmol 65(12):1350

18. Vasavada AR, Vasavada V, Vasavada S, Srivastava S, Vasavada V, Raj S (2015) Femtodelineation to enhance safety in posterior polar cataracts. Journal of Cataract \& Refractive Surgery 41(4):702-707

19. Kelman C (1994) V Groove phaco technique: Fast, easy, safe: Interview with Dr. Kelman. Ophthalmology Times 19(18):12

20. Vajpayee R, Sinha R, Singhvi A, Sharma N, Titiyal J, Tandon R (2008) 'Layer by layer'phacoemulsification in posterior polar cataract with pre-existing posterior capsular rent. Eye 
22(8):1008-1010

21. Salahuddin A (2010) Inverse horse-shoe technique for the phacoemulsification of posterior polar cataract. Can J Ophthalmol 45(2):154-156

22. Gupta S, Selvan H, Khokhar S (2019) Hook and flip technique: for phacoemulsification in nonrotating nuclei and posterior polar cataracts. Int Ophthalmol 39(6):1219-1223

23. Vasavada AR, Desai JP (1996) Stop, chop, chop, and stuff. Journal of Cataract \& Refractive Surgery 22(5):526-529

24. Bardoloi N, Sarkar S, Pilania A, Das H (2020) Pure phaco: phacoemulsification without ophthalmic viscosurgical devices. Journal of Cataract \& Refractive Surgery 46(2):174-178

25. Bardoloi N, Sarkar S (2021) A new technique of phacoemulsification without hydroprocedures. Kerala Journal of Ophthalmology 33(2):189

26. Hua X, Dong Y, Du J, Yang J, Yuan X (2018) Phacoemulsification with hydrodelineation and OVDassisted hydrodissection in posterior polar cataract. BMC Ophthalmol 18(1):165

27. Vasavada AR, Vasavada VA, Raj SM (2012) Approaches to a posterior polar cataract. Saudi J Ophthalmol 26(1):51-54

28. Malhotra C, Dhingra D, Nawani N, Chakma P, Jain AK (2020) Phacoemulsification in posterior polar cataract: Experience from a tertiary eye care Centre in North India. Indian J Ophthalmol 68(4):589

\section{Figures}

\section{Figure 1}

(a \& b) Approximately $5 \mathrm{~mm}$ capsulorhexis is performed by using $30 \mathrm{G}$ cystitome under irrigation, (c) Shaving of the cortex and epinucleus done within capsulorhexis area, (d) Primary chop and division of the nucleus into two halves done using chop in technique, (e) Nucleus is held at 7 o'clock position and chopping being done to take out a triangular piece of the nucleus, (f) Similar chopping performed at a 4 o'clock position of the nucleus with subsequent removal of a triangular piece of the nucleus, $(\mathrm{g})$ The phaco tip and the chopper are being positioned at the cracked site of the lower two fragments. (h)Using the two instruments, the fragments are pushed in the opposite direction and quickly taken out one after another, (i)The last nuclear pieces can be emulsified very easily, (j) The epinuclear sheet comes out very easily and can be aspirated with the phaco probe with lower parameters, $(k)$ Injection of viscoelastic agents before removing the phaco probe to prevent the collapse of the AC, (I) Intraocular lens (IOL) implanted in the capsular bag.

\section{Supplementary Files}

This is a list of supplementary files associated with this preprint. Click to download. 
- PPCVideofile1.mp4

Page 13/13 